\title{
Assessing (In)security after the Arab Spring: The Case of Egypt
}

\author{
Mohammad Ayatollahi Tabaar, Texas A\&M University
}

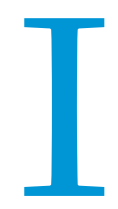

$\mathrm{n}$ nearly three years, Egypt has transitioned from a large-scale uprising against one of the region's longeststanding rulers to an even more massive revolt that led to the military ousting the country's first democratically elected president, Mohamed Morsi. Between the two popular uprisings, new pacts and unlikely alliances emerged, deepened, and, in some cases, then disappeared. For its part, the army evolved from being an accomplice of the old regime, to then being an uneasy partner of the ascendant Muslim Brotherhood and, most recently, on to rebranding itself as an ally of non-Islamists and a protector of the popular will. Loosely aligned liberals, leftists, and nationalists, meanwhile, shifted from offering support for democratic elections to backing a "democratic" coup out of fear that the elected Islamists might monopolize and never relinquish power in a conservative new regime. That fear came in response to the Brotherhood's own shifting position, which moved from a commitment to "participation not domination" to a strategy of controlling the legislature and the presidency, although they were ultimately forced back into hiding before they could neutralize the judiciary and the army. And finally, the other Islamist movement, the ultraconservative Salafists, initially displayed no interest in the political process, but then mobilized and ultimately enjoyed striking success in the elections of 2011-12. Surprisingly, however, despite their presumed ideological proximity to the Brotherhood, many Salafists went on to back the military's removal of Morsi in July 2013, but then did not lend support to the interim government that was constructed in wake of Morsi's fall. In this multilayered, fastpaced political environment, mass protests, arrests, and violence have become routine.

Egypt's protracted process of regime restructuring began on February 11, 2011, after street demonstrations in Cairo brought an end to Hosni Mubarak's 3o-year rule. Although the uprising had been initiated by diverse sets of grass-roots activists, the Supreme Council of the Armed Forces (SCAF) seemingly chose to protect its political and economic interests by severing ties with the president, conceding to the demands of the street opposition, and facilitating Mubarak's resignation. Mubarak's fall opened the door for Egypt's oldest Islamist organization, the Muslim Brotherhood, to emerge as the leading political player in the new Egypt. ${ }^{1}$ That door was then opened wider by the weakness of the so-called secular parties, which were racked by internal divisions and organizational inexperience during their campaign for the parliamentary elections of November 2011 and January 2012. Islamist parties, by contrast, remained cohesive and used their vast social networks among working-class and rural voters to mount formidable campaign efforts. In the end, the Muslim Brotherhood's Freedom and Justice Party (FJP) ${ }^{2}$ won nearly half of the available seats, while the ultraconservative (Salafist) al-Nour Party secured almost a quarter of the seats $(B B C N$ News 2012b). ${ }^{3}$ When presidential elections were held in mid-2012, liberal and other non-Islamist groups again focused their attention on competing against each other or attacking the SCAF, which allowed the Muslim Brotherhood's Mohamed Morsi and Mubarak's final prime minister, Ahmad Shafiq, to emerge as winners in the first round of the ballot. After Morsi narrowly won the second-round vote in June 2012, he became Egypt's first freely elected president (Kirkpatrick 2012c).

Problematically, Morsi's election did not resolve disputes about who should control the process of transition in Egypt; nor did it settle debates about how that process should be managed. To the contrary, the months that followed Morsi's election were marked by a series of highly fraught political confrontations between political and state actors who held fundamentally differing visions of the post-Mubarak era. In one confrontation, Morsi challenged the Supreme Constitutional Court for control over the country's parliament and, in another, Egypt's fractured non-Islamists took to the streets to challenge Morsi's attempt to control the constitution-writing process (Abdelaziz 2012; Kirkpatrick 2012d; Kirkpatrick and El Sheikh 2012). Meanwhile, the agencies of Egypt's vast military and security apparatus initially seemed more interested in securing their own positions in the post-Mubarak regime than they did in facilitating negotiations and agreement about what form that regime should take (Awad 2012). This fragile combination of political confrontation and security agency ambivalence, along with a disproportionate use of force from those agencies, gave rise to significant transitional violence on the streets of Egypt throughout 2012 and into the new year.

Over the early months of 2013, deepening economic and financial problems (such as diminishing foreign currency reserves and growing poverty and massive unemployment) exacerbated existing tensions and, in so doing, brought the country to the verge of chaos. In that climate, an unlikely alliance emerged between non-Islamists, the army, remnants of the Mubarak regime, and even the Salafists against the man they viewed as an inept and autocratic president who was "Ikhwanizing" ("Brotherhoodizing") the state and the new regime. On June 30, 2013, precisely one year after Morsi took office, millions of protesters gathered in Tahrir Square to demand that Morsi step down or, in case of refusal, that the very same army, so despised under Mubarak, intervene. Donning its new hat as defender of the popular will, the SCAF insisted that the president respond to the demands of street protestors and 
resolve the crisis in two days. When the defiant Morsi rejected the army's ultimatum and insisted that he would manage reforms his own way and on his own timetable, the military stepped in to depose and detain the standing president, along with hundreds of other top leaders of the Brotherhood (ElDin 2013; Reuters 2013; Saleh and Alsharif 2013).

Egypt then found itself back to square one: a caretaker government was installed by the army and a timetable was drawn up for (a second) transition to elected government. While the liberals, leftists, and nationalists are hoping to "get it right this time," many Islamists are resentful of their treatment in the immediate past and refuse to take any governmental role that might be offered in the immediate future. Only the army seems well-positioned in the aftermath of what, for all practical purposes, amounted to a coup. Whether the ongoing conflict is understood as a clash between secular and religious fundamentalisms (Ajami 2013) or a confrontation between illiberal democrats and undemocratic liberals (Shehata 2013), Egypt has never been so polarized. very same Islamists whom the security forces systematically repressed for decades controlled the presidency and the parliament for one year. In fact, despite early promises of security sector reform from the Brotherhood's FJP, the SCAF and the leadership of the Muslim Brotherhood initially confounded many observers' expectations by realizing something of an informal alliance or cohabitation-an apparent marriage of convenience between parties that recognized one another's strength. ${ }^{4}$ For the security services, that strength was rooted in its hard power and vast financial capital (the military is thought to control somewhere between $10 \%$ and $40 \%$ of Egypt's economy) (Fleishman 2012; Tadros 2012). The power of the Brotherhood, meanwhile, was (and remains) based on robust organizational structure and broad social capital, which it built by providing diverse social services to Egyptians at the grassroots level for decades. During the early period of Brotherhood rule, the two parties seemed to mutually recognize that their two-quite different-sources of strength meant that each actor was too powerful to be brought under the control of the

\section{During the early period of Brotherhood rule, the SCAF and the FJP seemed to mutually recognize that their two-quite different-sources of strength meant that each actor was too powerful to be brought under the control of the other.}

To understand the impact of that polarization on security in transitional Egypt, this article adopts the tripartite framework for understanding transitional violence that John Gledhill describes in this symposium's introduction (see "Editor's Introduction"). In the first scenario, collective violence occurs when a state's security apparatus fails alongside transition. The logic of the security dilemma may then lead "competing groups to arm, and counter-arm, until such a point as one faction feels compelled to take preemptive action against ostensibly threatening rivals." In the second scenario, fierce rivalry between political actors who have an interest in controlling the transitional government or the process of transition may pave the way for violence. And in the third scenario, transitional violence is a by-product of competition among state security services for power and position in the new regime. In the sections that follow, each of these scenarios is discussed in reference to the Egyptian case, in order to explain both variations in the presence or absence of violence that has already been seen alongside Egypt's transition since early 2011 as well as to assess the prospects for future violence.

\section{ASSESSMENT FRAMEWORK 1: DILEMMAS OF SECURITY?}

There is little or no immediate likelihood that the Egyptian state will dissolve into a condition of anarchy, giving rise to a security dilemma and a spiral of violence toward large-scale, sustained collective violence. That said, the capacity and willingness of state forces to maintain peace on the streets since Mubarak's fall has weakened, which has opened up opportunity space for episodic rioting and disorder throughout the country.

Egypt's two-million-strong security apparatus has remained in place since the fall of Mubarak, despite the fact that the other. Consequently, the expected confrontation between Egypt's "deep state" and what can be termed its "deep society" turned into a collaboration that allowed the security services to remain intact and largely unreformed. 5 External actors, including the United States (despite some opposition from Congress), seemingly acquiesced to that arrangement-perhaps believing that collaboration between the Brotherhood and the military would bolster short-term stability in Egypt and, therefore, the region (Baker and Kirkpatrick 2012; Brownlee 2012; Ezzat 2013; Ninan and Hughes 2012).

While the formal structures of Egypt's military and vast police services remained in place, the capacity and/or willingness of those organizations to successfully maintain their monopoly on violence in Egypt weakened after Mubarak's fall. The sources of that enfeeblement were diverse, but they included two factors in particular: internal divisions within the security apparatus (largely between senior officers and their younger, "reformist" counterparts) and inadequate training in riot-control policing (Ashour 2012; Loveluck 2013). Regardless of origins, however, a weakening of state sanctioning allowed for repeated outbreaks of street riots. In one case, attacks on Coptic Christians in October 2011 were conducted under the watch of a military and riot police that, at first, seemed incapable of managing the situation. However, when it became apparent that state forces may have been involved in fomenting those attacks, concerns emerged that the state was simply not willing to protect a politically weak minority in the new Egypt. ${ }^{6}$ The limitations of the state's responses to street violence were again evident in early 2012, when police failed to contain riots that broke out following a soccer match in Port Said (Kirkpatrick 2012b), and once more in January 


\section{Figure 1 \\ Map of Egypt}

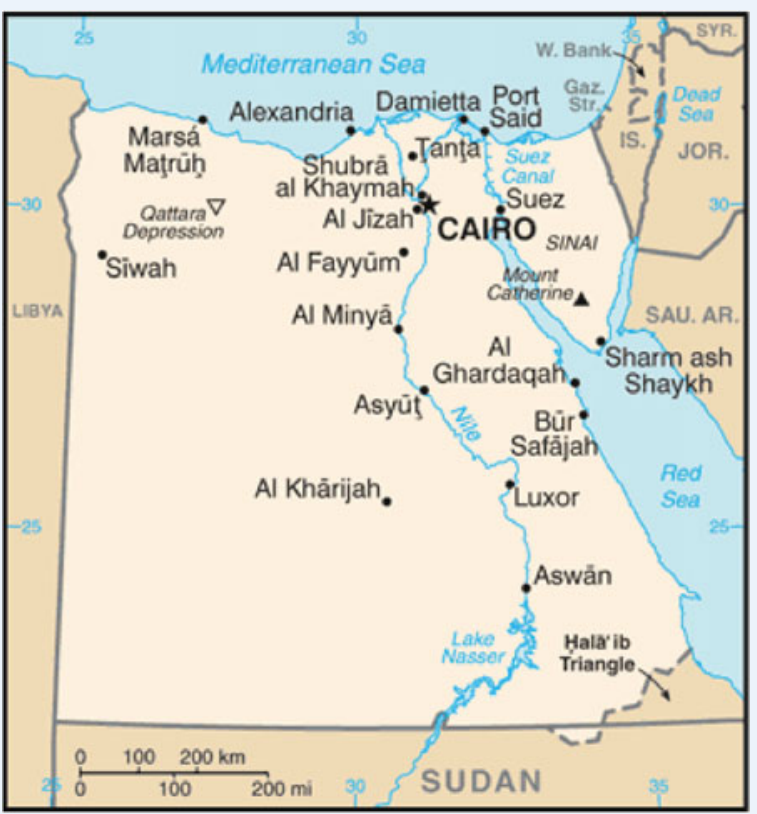

From The World Factbook 2013-14, Washington, DC: Central Intelligence Agency, 2013. The Factbook is in the public domain (visit https://www.cia.gov /library/publications/the-world-factbook/index.html) (Color online.)
2013, when a renewed wave of antigovernment protests and violence swept through the cities of Port Said, Suez, and Ismailia. (See figure 1.) The police were seemingly so strained at that time that they did not bring the situation under control swiftly, even after then-President Morsi afforded their forces extraordinary powers in those cities.

As violence persisted, Defense Minister Abdul Fattah el-Sisi warned that confrontations between competing political factions were wearing down state security forces in a way that threatened to precipitate a "collapse of the state" (Kirkpatrick 2013). In practice, however, that outcome seemed highly unlikely. Instead, el-Sisi's claim may have been a warning to the ruling Brotherhood, political activists, and angry street protesters of the need for deference to the state (Stacher 2013). In fact, the sudden reappearance of the police in the streets in the aftermath of the July 3 coup seems to support the longheld suspicions of some observers that security forces had been unwilling, rather than incapable, of cooperating with the Morsi government over the previous year (Hubbard and Kirkpatrick 2013). Those suspicions mounted further after the security services used extreme force in several bloody crackdowns on Brotherhood supporters who took the streets in protest following Morsi's removal. In the most bloody attacks (at the time of writing), security forces fired on Morsi supporters who had formed sit-in protests on the streets of Cairo and other cities throughout July and August, killing hundreds and wounding thousands (BBC News 2013a; $B B C$ News 2013d; $B B C$ News 2013e; Dziadosz and Nasralla 2013). On August 14, a state of emergency was declared, which threatened a return to Mubarak-era security.
The security services have applied their force to deadly ends since the fall of Morsi; nevertheless evidence continues to suggest that state capacity remains somewhat enfeebled. That evidence comes in the form of the failure of the army and the post-Morsi government to swiftly reassert control over the increasingly lawless region of Sinai. Called "Egypt's Afghanistan," the sparsely populated Sinai Peninsula has become a fertile ground for Islamist militants, who threaten Egypt and beyond (Bradley and El Ghobashy 2013; The Economist 2013). In recent years, the Sinai insurgents have acquired heavy weapons from Libya, ambushed Egyptian security forces, attacked tourists in Egypt's Sharm el-Sheikh and Israel's Eilat resorts, bombed gas pipelines running through the Sinai to Israel and Jordan, and smuggled weapons to Gaza (Fahmy 2013). If al-Qaeda associates, other militant Islamists, and disgruntled Bedouins in the Sinai forge an alliance with those members of the Brotherhood and/or Salafists who have radicalized in response to the coup and security forces' subsequent brutality, the area could turn into a long-term security challenge-one that could incapacitate the state. The Brotherhood's track record of choosing peaceful opposition over violence suggests they would not be party to such an alliance. However, some resentful members of the Brotherhood may dissent and follow groups that pursue violent means. The resulting alliance would be a potential threat which, in the extreme, could give rise to a dynamic reminiscent of Algeria's bloody civil wars of the 1990 .

\section{ASSESSMENT FRAMEWORK 2: DILEMMAS OF GOVERNANCE?}

While a multiplicity of political actors have emerged in postMubarak Egypt, there are arguably two primary vectors of political party confrontation: liberal and secular non-Islamists versus the Muslim Brotherhood, on one side, and Salafists versus both the Brotherhood and liberals, on the other. In each of these match-ups, the Brotherhood initially seemed to enjoy a significant power advantage over its competitors because of the movement's vast organizational framework, significant material resources, and long-established political experience. Although the Brotherhood had originally promised to restrain its ambitions and not translate that informal power into a dominance of formal political institutions, the movement ultimately contested-and dominated-the parliamentary elections of 2011-12 and the presidential ballot of $2012 .^{7}$ Brotherhood leaders then proved adept at using various domestic legal devices to shore up their immediate hold on power and, in November 2012, Morsi moved to further consolidate that power by issuing a controversial decree that essentially put the presidency above judicial review. That move prompted swift international condemnation, opposition demonstrations, and violence on the streets of the capital in late $2012 .{ }^{8}$ Although the then-president responded to early protests by repealing a number of divisive aspects of the law and inviting representatives of the opposition to present their grievances, that nod to pluralism was accompanied by a legal provision that empowered army officers to arrest civilians in the run-up to the constitutional referendum of December 2012 and elections for the lower house of parliament, which were initially 
scheduled for April 2013. ${ }^{9}$ The Brotherhood also enjoyed indirect external support in its effort to consolidate power; it was not coincidental that the president issued his controversial decree only days after he was lauded abroad for brokering a ceasefire between Hamas and Israel, and a short time after the International Monetary Fund (IMF) agreed to offer Egypt's cash-strapped government a conditional loan of $\$ 4.8$ billion (Kirkpatrick and Rudoren 2012; Saleh and Blair 2012). That promise came in the wake of significant bilateral support from Saudi Arabia and in advance of a commitment from Qatar to invest $\$ 18$ billion in Egypt over the next five years (Ahram Online 2012a; Wall Street Journal 2013). ${ }^{10}$

In theory, the imbalance of power in favor of the Brotherhood could have reduced the likelihood of transitional violence in Egypt because rival factions might have recognized their comparative weakness and simply conceded control over the transition process to the Muslim Brotherhood. However, this was not the case. On the contrary, the potential for confrontation remained ever-present because diverse (and often divided) collections of opposition movements resisted the dominance by the Brotherhood, who were seen by their opponents as exploiting a revolution that had been initiated by youths, leftists, and liberals with the aim of pluralizing the system of government in Egypt. when a set of demonstrations that coincided with the second anniversary of Mubarak's fall evolved into anti-Brotherhood riots in Port Said and other cities around the Suez Canal. ${ }^{11}$ The degree to which the riots reflected national-level political concerns remains unclear because it appears that much of the violence was perpetrated by local actors who were frustrated at the lack of attention being given to their local-level grievances. Regardless of the motives of the rioters, the high cost of the January violence (more than 50 deaths were reported at that time) provided a wake-up call to all parties in Egypt. In their immediate wake, all major political parties attended a meeting hosted by al-Azhar Grand Imam Ahmed el-Tayeb at his Cairo headquarters, where an appeal was made for nonviolence (Al-Yourn 2013; El Gundy 2013). The responsibility for ensuring peace was to be borne by state security forces, the government, and all opposition movements. Although the agreement offered hope that political competition between the Brotherhood and diverse non-Islamist opposition groups would be peaceful going forward, the notable absence of the Ministry of the Interior from the talks raised concern over the state's willingness to guarantee the agreement (Radwan 2013).

Despite talk of cooperation, relations between the Muslim Brotherhood and all other parties dissolved over the first half 2013, in part because Morsi failed to manage a series of state

\section{While a multiplicity of political actors have emerged in post-Mubarak Egypt, there are arguably two primary vectors of political party confrontation: liberal and secular non-Islamists versus the Muslim Brotherhood, on one side, and Salafists versus both the Brotherhood and liberals, on the other.}

By and large, during Morsi's rule, confrontations between supporters of the Brotherhood and those opposed to the main Islamist movement unfolded on the streets of Egypt, rather than in the halls of formal political power, simply because the nonIslamist factions had a relatively weak presence in the parliament but a relatively strong network of young social activists, who could draw on their experience of mobilizing popular protests during the uprising of January-February 2011. That shared experience united liberal and secular groups in early 2011, but their movement became highly fractured in the wake of Mubarak's fall. Still, several attempts were made to bring opposition groups together under a united banner. For instance, in November 2012, a host of liberal, nationalist, and left-wing groups formed the National Salvation Front to collectively voice their opposition to Morsi's controversial move to place himself above judicial review (Ahram Online 2012d). Although the street protests that followed were initially peaceful, the situation on the ground descended into violence in early December 2012, when anti-Brotherhood demonstrators marched to the presidential palace and were confronted by agitators who were aligned with the ruling party (The Guardian 2012).

After a period of (relative) calm, during which the constitution was passed through an accelerated referendum process, political violence returned to Egypt in late January 2013, crises effectively. Consequently, opposition to Morsi's rule began to coalesce among a wide array of activists, who were drawn from groups as diverse as the April 6 Youth Movement, liberal political parties, the Coptic Church, the al-Azhar Sheikh, the Salafist al-Nour Party, and even remnants of the Mubarak regime. The bleeding economy was a particularly galvanizing issue and one that affected millions of poor citizens. Following the January 25 upheaval, for example, inflation surged from $3 \%$ to $18 \%$, government debt grew from $\$ 30$ billion to $\$ 40$ billion, debt payment jumped from $\$ 5$ billion to $\$ 8$ billion per annum, and international reserves melted from $\$ 36$ billion to $\$ 15$ billion. Within two and half years, the share of the Egypt's citizens living on less than $\$ 2$ per day rose from $40 \%$ to $50 \%$ (Daragahi 2013; Dorell 2013; Egypt Independent 2013a). In that climate, Morsi could not increase taxes, remove subsidies, or impose other austerity measures-at least not without prompting popular backlashes. But in the absence of such structural reforms, the initial $\$ 4.8$ billion agreement with the IMF stalled. At the same time, financial assistance from Libya, Turkey, Saudi Arabia, Qatar, and the United States was not sufficient to stop the economy from sinking and, with it, popular support for the Brotherhood.

Beyond economic pain, many feared the "Ikhwanization" of the state and indefinite domination at the hands of Islamist 
governments. While there was a host of bases for that fear, certain key moves by the Morsi presidency generated widespread concern. One particularly controversial step was the imposition of restrictions on the media and nongovernmental organizations, which curtailed freedom of speech. Another move that antagonized Egyptians was Morsi's illfated appointment of a number of radical Islamist governorsincluding a member of Gamaa Islamiya, who was invited to run the ancient city of Luxor. Because Gamaa Islamiya has been responsible, in the past, for attacks on tourists, Coptic Christians, and the police, that appointment sparked anger throughout the country in June 2013 (Hassieb 2013). In less than a year, Morsi's $80 \%$ popularity had melted. ${ }^{12}$

In April 2013, the grassroots Tamarod (Rebel) movement was born and it rapidly won the backing of a wide spectrum of the Brotherhood's opponents (BBC News 2013c). After claiming to collect 22 million signatures in support of Morsi's resignation, Tamarod called for a mass demonstration to gather in Tahrir Square on June 30-the first anniversary of Morsi taking office. Tamarod issued an ultimatum for him to step down or face civil disobedience. When the anti-Morsi street protests proved to be massively popular, the army issued its own ultimatum for Morsi to meet the demands of the protestors within 48 hours. The president responded by warning were represented mainly by the al-Nour Party, enjoyed less success than the Brotherhood's FJP in the 2011 parliamentary elections, they still formed the second-largest bloc in the Shura Council (the upper house). They then slowly expanded their political base by forcing Morsi to incorporate some of their religious demands into the emerging regime arrangements during the constitution-drafting process. ${ }^{13}$ The Salafists' rise was a double-edged sword for the Brotherhood; it threatened the Brotherhood's position among the poor and religious conservatives on the far right, but it also broadened the Brotherhood's appeal by allowing the movement to emphasize its pragmatism at the expense of religious principles. Just as Mubarak used the supposed threat of political Islam as a pretext for repressing the Brotherhood and attracting domestic and international backing for his rule, the Brotherhood tried to politically benefit from internal and external fear about the rise of the ultraconservative Salafists. However, this tactic ultimately backfired. By June 2013, it was the Salafist al-Nour Party that teamed up with the non-Islamists against Morsi. Although they did not participate in the anti-Brotherhood rallies, the party joined other opposition leaders in calling for the SCAF to remove Morsi. This was not the case with all Salafist parties, however; other factions, including the al-Watan Party (formed

\section{It is ironic, therefore, that el-Baradei later became a leading figure in a movement that appealed to the army to save the revolution by removing Morsi.}

against removing a legal, constitutional, and legitimate government. Military leaders chose not to heed those warnings, however, and they ousted Morsi from the presidency on July 3, 2013 .

Soon after Morsi was deposed, the temporary alliance of those opposed to his rule splintered. Tamarod rejected a Constitutional Decree that was put together by the militarybacked interim government, claiming that it was dictatorial because it included key articles related to sharia and military courts-moves that were designed to appease the Salafists and the army, respectively (Egypt Independent 2013b). It later launched "Write Your Own Constitution" and called for a new constitution to be drafted from scratch (Egypt Independent 2013c). Meanwhile, the Salafist al-Nour Party blocked Mohammad el-Baradei's appointment as interim prime minister, although he was later sworn in as an interim vice president. El-Baradei, who is a leader of the liberal opposition and Nobel laureate, had pulled out of the presidential bid in 2012 because of the continued military grip on power. It is ironic, therefore, that el-Baradei later became a leading figure in a movement that appealed to the army to save the revolution by removing Morsi (Taha 2013). However, he later resigned as acting vice president in reaction to the brutality shown by the security forces during their efforts to clear pro-Morsi protest camps in August.

Overall, Egypt's fitful transition appears to be strengthening the hand of ultraconservatives. Although Salafists, who by defectors from al-Nour in January 2013) sided with the Brotherhood.

The decision of al-Nour to "abandon" Morsi and the Brotherhood surprised some observers, but the move could have been foreseen. After all, party leaders had repeatedly made it clear that they would never form a coalition with the Muslim Brotherhood because of fundamental differences of doctrine (Al Arabiya 2013; Elyan and al-Yamani 2011). Those differences between al-Nour and the Brotherhood never escalated into confrontations on Egypt's streets, partly because of increasing divisions within the party, and partly because some conservatives ensured that aspects of the new constitution were drafted in accordance with their reading of sharia. ${ }^{14}$ Interestingly, the army chose to keep some of those provisions in the Constitutional Declaration after its coup, to reward al-Nour for not standing with Morsi.

Despite divisions among Salafists, they are continuing to gain political ground. Thus, going forward, they may become a power broker and the leading Islamist force, particularly if the Brotherhood remains absent from the electoral process. Given their ultraconservative stance, rising Salafists could face strong resistance from an alliance of non-Islamist opposition groups and the army. The Salafists' exclusion could then unite and push them back toward the disenfranchised Brotherhood or, more ominously, the most radical Islamists, who are now calling for an armed uprising (Al-Anani 2013; McCants 2013; Ottaway 2013). 


\section{ASSESSMENT FRAMEWORK 3: SECURITY} SECTOR DILEMMAS?

Egypt's state security apparatus has remained intact and largely unreformed across the change of regime, which means that there has been little opportunity for the development of competition (and associated violent confrontation) between the various branches of Egypt's vast security sector. This institutional continuity has been underwritten by a diverse set of actors, holding a diverse set of interests. On the military side of the equation, the existing economic and political strength of the military means that the SCAF has had a clear interest in resisting real structural change. And on the police side, the Morsi government's reluctance to substantially reconfigure either the Central Security Forces or the State Security Investigations Services (renamed the Homeland Security Agency) seems to have been driven by fear that major restructuring would weaken those organs at the exact time that their support was most needed, given recurrent street violence (Ashour 2012; Brumberg and Sallam 2012; Stacher 2013). A third factor working against substantial security sector reform has been that the military and police have not pressed one another to mutually restructure. In fact, rather than competing among each other for position in the new regime, it seems that the organs of the Ministries of Defense and Interior have cooperated to ensure that security actors-collectively-remain powerful players in the post-Mubarak era (Brumberg and Sallam 2012). military to be brought under civilian control and internally restructured. Moves in that direction taken during Morsi's rule suggested that two potential strategies of security reform were under consideration, either of which could be pursued by a future civilian government, particularly one that is led by a political party that is keen to assert independence from the military.

In one scenario, an elected government would not only focus on bringing existing services under civilian control; it would also establish one or more parallel security services, which would come under the direct command of the government. Speculation that Morsi was considering this arose in early 2013, when it was reported that advisers to the thenpresident had met with a commander from Iran's Revolutionary Guards for advice on establishing an independent security or intelligence agency (Tomlinson 2013). Such a strategy may appear attractive to any future civilian government because it would strengthen the political hand of the government vis-àvis the military. However, it would come with risks in terms of internal stability because existing security structures could take umbrage and, perhaps, take action, against any new agency that threatened to draw power and resources away from incumbent services.

In a second potentially volatile scenario, security sector reforms could be realized with significant material assistance and counsel from Western states. Speculation about this possibility grew in the wake of a meeting between Morsi and

\section{Although internal resistance to change had blocked substantial reforms, Morsi gave some credence to the Brotherhood's early promise to rein in the power of the security services by removing a set of Mubarak-era generals from the security hierarchy.}

Although internal resistance to change had blocked substantial reforms, Morsi gave some credence to the Brotherhood's early promise to rein in the power of the security services by removing a set of Mubarak-era generals from the security hierarchy. Most notably, he pressed Field Marshal Hussein Tantawi to step down as defense minister and head of the SCAF in August 2012. The heads of the air force and navy were also dismissed, as were an additional 70 army generals some weeks later (BBC News 2012a). Curiously, those moves were not met with significant objections from within the ranks of the military. This lack of reaction suggested that junior officers who had long waited in the wings for promotion were happy to countenance the forced retirement of their seniors, so long as such intervention did not threaten the security sector's overall political, strategic, and economic interests (Ashour 2012; Loveluck 2013; Sallam 2012b).

With Morsi's removal by the military, and the military's involvement in the transitional government of Egypt, substantial security sector reform seems to be off the table at present. The security apparatus is in the game with full force. Over the long term, however, a possible return to full civilian government is likely to be accompanied by renewed demands for the
British Prime Minister David Cameron, when it was agreed that a team of British security experts would advise Egyptian forces on stabilization measures (Watt 2012). Following that agreement, there were more offers of security reform assistance from Western countries. Although such offers have likely been put on ice while the political situation in Egypt settles, it can be fairly assumed that offers of outside support for security sector reform would resurface following the reinstallation of an elected government. This support could facilitate a democratization of Egypt's security services, but it could also generate divisions within the military by raising the ire of those powerful officers who continue to fear a Western conspiracy against Egypt (Ashour 2012).

\section{CONCLUSION}

Nearly three years since the January 25 uprising, Egypt's key players are in a fierce battle to reappropriate their "revolution" from those they consider to be traitors and free-riders. Relentless non-Islamists ousted the Brotherhood, which they believed had "hijacked" the 2011 revolution, by forging an alliance with the army and bringing millions of protesters back to Tahrir Square. Opponents accuse the Muslim Brotherhood 
of conspiring with the army, the United States, and even Israel during their brief time in power. Meanwhile, the Brotherhood, which patiently waited more than eight decades to attain power, view themselves as the victims of a conspiracy of the old guard, which supposedly collaborated with liberals, other non-Islamists, and external forces to remove a party that legally won five free elections. Amidst this jockeying for control, the SCAF has expanded its institutional power, prowess, and popularity. Each of Egypt's two transitions has allowed the army to win more autonomy from civilian oversight and more political leverage against challenging parties.

Unless Egypt's main political forces arrive at a compromise or reconciliation, violence will continue to breed more violence. A country that had only one president for 30 years, now has an ex-president on trial, another president detained, an interim president in office, and it will soon have a new president if the promised elections are held. Each of those who have held presidential office represents a deeply rooted force with some claim to power in Egypt, and some support for that claim. In this zero-sum game, the danger is that parties will use the streets as a battlefield to determine how power is distributed among them in the new Egypt.

\section{ACKNOWLEDGMENTS}

The author thanks April Alley, Nathan Brown, Caitlin Elizabeth Browne, Mohamed Elmenshawy, John Gledhill, Reyko Huang, Ahmed Morsy, Hesham Sallam, Erin Snider, and Dina Zayed for their valuable comments and Shira Babow, Jessica Koloini, and Meghan McCaffrey for their excellent assistance. -

\section{NOTES}

1. For an excellent analysis of the unintended consequences of the fall of Mubarak for Islamist forces see Brown (2013a). For a history of the Muslim Brotherhood's political transformation in Egypt, see El-Ghobashy (2005). Also see, Brown (2012).

2. The Freedom and Justice Party was formed by the Muslim Brotherhood within weeks after Mubarak's fall.

3. For more on the rise of the Salafists, see Lacroix (2012).

4. For more on the history of the relationship between the army and the Brotherhood, see Eskandar (2013). On security sector reform, see Ashour (2012), Brumberg and Sallam (2012), and Loveluck (2013).

5. For more on the role of the army in the post-Mubarak Egypt, see Hellyer (2012), Mackey (2012), Nakhoul (2012), Sallam (2012a), Sallam (2012b), and Stacher (2012).

6. For an account of these debates and events, see BBC News (2011), Human Rights Watch (2011), Hassan (2011), and Kirkpatrick (2011).

7. For reactions to the Brotherhood's increasing presence in Egypt's political institutions, see Hassieb and Fadel (2012) and Maged (2012).

8. Condemnation of the November 2012 decree came from within Egypt and abroad. See, for example, Lambert and Felsenthal (2012), Fahim and Kirkpatrick (2012), and Hill (2012).

9. See Ahram Online (2012b), Beaumont (2012) Bradley (2012), and Human Rights Watch (2012).

10. Saudi Arabia carefully maintained political distance from Morsi and went on to provide massive financial support for the interim government immediately following his removal. But Qatar remained Morsi's key ally until he was ousted.

11. Violence in the Suez region was initially sparked by a court decision, which handed down 21 death sentences in relation to the soccer riots of February 2012; see BBC News (2013b).

12. On the popularity of Morsi, see Ahram Online (2013a), Ahram Online (2013b), Ahram Online (2012c).
13. On the role of the Salafists in the constitution-drafting process, see Salem (2012) and Kirkpatrick (2012a).

14. For more details of the recent divisions within the Salafists, see Revkin and Samaan (2012) and Al Jazeera (2013).

\section{REFERENCES}

Abdelaziz, Salma. 2012. "New Egypt President Takes on Military Over Parliament." CNN, July 2. http://www.cnn.com/2012/07/02/world/africa/egypt -politics.

Ahram Online. 2012a. "Egypt's Morsi Discusses \$8.5bn in Saudi Investments." September 11. http://english.ahram.org.eg/NewsContent/3/12 /52537/Business/Economy/Egypts-Morsi-discusses-bn-in-Saudiinvestments.aspx.

. 2012b. "Egypt's President Morsi to Allow Military to Arrest Civilians." December 8. http://english.ahram.org.eg/News/60o34.aspx.

- 2012c. "Morsi's Approval Rating Nears 80\% after 8o Days in Office: Baseera Tracker.", September 28. http://english.ahram.org.eg /NewsContent/1/140/53872/Egypt/The-Balance-Sheet/Morsis -approval-rating-nears-after-days-in-offic.aspx.

_. 2012d. "Sabbahi, ElBaradei Launch National Front to Fight Morsi's Decrees.” November 24. http://english.ahram.org.eg/NewsContent/1/64 /59068/Egypt/Politics-/Sabbahi,-ElBaradei-launch-National-Front-to -fight-.aspx.

_ 2013a. "44 pct of Egyptians Not Willing to Re-elect President Morsi: Baseera Poll." February 11. http://english.ahram.org.eg/News/64449.aspx.

- 2013b. "71\% of Egyptians unsympathetic with pro-Morsi Protests." Ahram Online, July 22. http://english.ahram.org.eg/News/77085.aspx.

Ajami, Fouad. 2013. "Egypt's Islamists are Out but Not Down." The Washington Post, July 12. http://www.washingtonpost.com/opinions/egypts -islamists-are-out-but-not-down/2013/07/12/1do8752e-ea45-11e2-a301 -ea5a8116d211_story.html

Al-Anani, Khalil. 2013. “The Nour Party's Perilous Gamble.” Al Monitor, July 22. http://www.al-monitor.com/pulse/originals/2013/o7/nour-party -perilous-gamble-backing-morsi-ouster.html.

Al Arabiya. 2013. "Egypt's Salafi Party Says No Alliance with Brotherhood Next Elections." January 12. http://www.alarabiya.net/articles/2013/o1 /12/259973.html.

Al Jazeera. 2013. "Egypt's Salafis Split Ahead of Elections.” January 14. http://m.aljazeera.com/story/2013114105047960749.

Al-Yourn, Al-Masry. 2013. "Al-Azhar Grand Sheikh Summons Political Forces for Talks to End Violence." Egypt Independent, January 31. http:// www.egyptindependent.com/news/al-azhar-grand-sheikh-summons -political-forces-talks-end-violence.

Ashour, Omar. 2012. "From Bad Cop to Good Cop: The Challenge of Security Sector Reform in Egypt." Brookings Doha Center-Stanford Project on Arab Transitions (3): 1-17. http://www.brookings.edu/ /media/research /files/papers/2012/11/19\%20security\%20sector\%2oreform\%20ashour /omar\%2oashour\%2oenglish.pdf.

Awad, Marwa. 2012. "Egypt Army Gets Temporary Power to Arrest Civilians." Reuters, December 10. http://www.reuters.com/article/2012/12/10/us -egypt-politics-army-idUSBRE8B9oDU20121210.

Baker, Peter, and David Kirkpatrick. 2012. "Egyptian President and Obama Forge Link in Gaza Deal." New York Times, November 21. http:// www.nytimes.com/2012/11/22/world/middleeast/egypt-leader-and -obama-forge-link-in-gaza-deal.html.

$B B C$ News. 2011. "Egypt Clashes: Copts Mourn Victims of Cairo Unrest." October 10. http://www.bbc.co.uk/news/world-middle-east-15242413.

_. 2012a. "Egypt Retires 7o Army Generals." September 2. http:// www.bbc.co.uk/news/world-middle-east-19456182.

_. 2012b. "Egypt's Islamist Parties Win Elections to Parliament." January 21. http://www.bbc.co.uk/news/world-middle-east-16665748.

_. 2013a. "Egypt President Adly Mansour in First Public Address." BBC News, July 18. http://www.bbc.co.uk/news/world-middle-east-23369580.

. 2013b. "Egypt Protests Continue Despite Overnight Curfew." January 29. http://www.bbc.co.uk/news/world-middle-east-21240604.

_. 2013c. "Profile: Egypt's Tamarod Protest Movement." July 1. http:// www.bbc.co.uk/news/world-middle-east-23131953.

_. 2013d. "Egypt Crisis: 'Scores killed' at Cairo protest." July 27. http:// www.bbc.co.uk/news/world-middle-east-23474645. 
. 2013e. "Egypt Crisis: Cairo Quiet but Tense as Death Toll Rises." August 15. http://www.bbc.co.uk/news/world-middle-east-23707439.

Beaumont, Peter. 2012. "Mohamed Morsi Bars Court Challenges and Orders Hosni Mubarak Retrial." The Guardian, November 22. http://www .guardian.co.uk/world/2012/nov/22/mohamed-morsi-mubarak-retrial -egypt.

Bradley, Matt. 2012. "Egypt's Morsi Partially Annuls Decree Expanding His Powers." Wall Street Journal, December 8. http://online.wsj.com/article /SB10001424127887323316804578167292051677944.html.

Bradley, Matt, and Tamer El Ghobashy. 2013. "Egypt's Coup Sparks Rising Chaos in Sinai." Wall Street Journal, July 22. http://stream.wsj.com/story /latest-headlines/SS-2-63399/SS-2-282379/.

Brown, Nathan. 2012. When Victory Is Not an Option: Islamist Movements in Arab Politics. Ithaca, NY: Cornell University Press.

_. 2013a. "Islam and Politics in the New Egypt." Carnegie Endowment for International Peace, April. http://carnegieendowment.org/files /islam_politics.pdf.

. 2013b. "Egypt's Wide State Reassembles Itself." Foreign Policy, July 17. http://mideast.foreignpolicy.com/posts/2013/o7/17/egypt_s_wide _state_reassembles_itself.

Brownlee, Jason. 2012. Democracy Prevention: The Politics of the U.S.-Egyptian Alliance. New York: Cambridge University Press.

Brumberg, Daniel. 2013. “The Resurgence of the Egyptian State.” Foreign Policy, July 8. http://mideast.foreignpolicy.com/posts/2013/07/o8 /the_resurgence_of_the_egyptian_state.

Brumberg, Daniel, and Hesham Sallam. 2012. "The Politics of Security Reform in Egypt.” United States Institute for Peace, October. http:// www.usip.org/files/resources/SR318_o.pdf.

Daragahi, Borzou. 2013. "Egypt's Foreign Reserves Give Cause for Concern." Financial Times, May 8. http://www.ft.com/intl/cms/s/o/7oeb5 dba-b7f 4 -11e2-9f1a-00144feabdco.html\#axzz2ZzjJNCHE.

Dorell, Oren. 2013. "Egypt's Ailing Economy is at the Heart of the Unrest." USA Today, July 2. http://www.usatoday.com/story/news/world/2013 /o7/o2/egypt-morsi-economy/2482971/.

Dziadosz, Alexander, and Shadia Nasralla. 2013. "At Least 51 Killed in Egypt as Islamists Urge Defiance.” Reuters, July 8. http://www.reuters.com /article/2013/o7/o8/us-egypt-protests-idUSBRE95QoNO20130708.

The Economist. 2013. "Egypt's Sinai Desert: A Haven for Malcontents.” July 13. http://www.economist.com/news/middle-east-and-africa/21581782 -wake-muhammad-morsis-fall-sinai-becoming-even-more-dangerous -haven.

El-Din, El-Sayed Gamal. 2013. "Over 400 Pro-Morsi Protesters Detained by Egypt Prosecution.” Ahram Online, July 17. http://english.ahram.org.eg /NewsContent/1/64/76734/Egypt/Politics-/Over-proMorsi-protesters -detained-by-Egypt-prosec.aspx.

El-Ghobashy, Mona. 2005. "The Metamorphosis of the Muslim Brothers." International Journal of Middle East Studies 37: 373-95.

Egypt Independent. 2013a. "Foreign Reserves Drop to US\$14.9 bn at End of June." Egypt Independent, July 7. http://www.egyptindependent.com /news/foreign-reserves-drop-us149-bn-end-june.

. 2013b. "Tamarod: Constitutional Declaration Lays Foundation for New Dictatorship.” Egypt Independent, July 9. http://www .egyptindependent.com/news/tamarod-constitutional-declaration -lays-foundation-new-dictatorship.

_. 2013c. "Tamarod, NAC Want All-New Constitution." Egypt Independent, July 3 o. http://www.egyptindependent.com/news/tamarod-nac -want-all-new-constitution.

El Gundy, Zeinab. 2013. "Al-Azhar Unveils 10-Point Initiative to End Egypt's Political Crisis.” Ahram Online, January 31. http://english.ahram.org.eg /NewsContent/1/64/63759/Egypt/Politics-/AlAzhar-unveils-point -initiative-to-end-Egypts-pol.aspx.

Elyan, Tamim, and Muhammad al-Yamani. 2011. "Egypt Salafis Want No Pact with Muslim Brotherhood." Reuters, December 4. http://www.reuters .com/article/2011/12/o4/us-egypt-salafi-idUSTRE7B30MN20111204.

Eskandar, Wael. 2013. "Brothers and Officers: A History of Pacts." Jadaliyya, January 25. http://www.jadaliyya.com/pages/index/9765/brothers-andofficers_a-history-of-pacts.

Ezzat, Dina. 2013. "US Still Backing Morsi as Army Remains Quiescent." Ahram Online, January 29. http://english.ahram.org.eg/NewsContent /1/64/63559/Egypt/Politics-/US-still-backing-Morsi-as-army-remainsquiescent.aspx.
Fahmy, Mohamed Fadel. 2013. "The Jihadist Threat in Egypt's Sinai." Al Mon itor, July 22. http://www.al-monitor.com/pulse/originals/2013/o7 /jihad-threat-egypt-sinai.html.

Fahim, Kareem, and David Kirkpatrick. 2012. "Clashes Break Out After Morsi Seizes New Power in Egypt." New York Times, November 23. http:// www.nytimes.com/2012/11/24/world/middleeast/amid-protest-egypts -leader-defends-his-new-powers.html.

Fleishman, Jeffrey. 2012. "Battling for Egypt's Economy.” Los Angeles Times, March 25. http://articles.latimes.com/2012/mar/25/world/la-fg-egypt -military-20120325.

The Guardian. 2012. "Morsi Supporters Clash with Protesters outside Presidential Palace in Cairo." December 5. http://www.guardian.co.uk/world /2012/dec/o5/morsi-supporters-protest-presidential-palace-cairo.

Hassan, Amro. 2011. "Egypt Military says Soldiers Didn't Intentionally Kill Copts." Los Angeles Times, October 13. http://articles.latimes.com/2011 /oct/13/world/la-fg-egypt-military-denial-20111013.

Hassieb, Ingy. 2013. "Egypt's Morsi Sparks Anger with Islamist Picks for Top Posts." Los Angeles Times, June 20. http://articles.latimes.com/2013/jun /20/world/la-fg-wn-morsi-islamist-20130620.

Hassieb, Ingy, and Leila Fadel. 2012. "Egypt's Muslim Brotherhood Nominates Presidential Candidate." Washington Post, March 31. http:// articles.washingtonpost.com/2012-03-31/world/35448716_1_shater -abdel-moneim-aboul-fotouh-islamist-group.

Hellyer, H.A. 2012. "Hard Choices for Egypt's Military." Foreign Policy, July 23. http://mideast.foreignpolicy.com/posts/2012/07/23/hard_choices _for_egypts_military.

Hill, Evan. 2012. "Egyptian Judges Strike at Morsi Power Grab." The Times, November 24. http://www.thetimes.co.uk/tto/news/world/middleeast /article3610957.ece.

Hubbard, Ben, and David D. Kirkpatrick. 2013. "Sudden Improvements in Egypt Suggest a Campaign to Undermine Morsi." New York Times, July 10. http://www.nytimes.com/2013/o7/11/world/middleeast/improvements -in-egypt-suggest-a-campaign-that-undermined-morsi.html?pagewanted $=1 \& \_r=1 \& \mathrm{ref}=$ middleeast $\&$.

Human Rights Watch. 2011. "Egypt: Don't Cover Up Military Killing of Copt Protesters." October 25. http://www.hrw.org/news/2011/10/25/egypt-don-t -cover-military-killing-copt-protesters.

. 2012. "Egypt: Morsy Law Invites Military Trials of Civilians." Decem ber 10. http://www.hrw.org/news/2012/12/10/egypt-morsy-law-invites -military-trials-civilians.

Kirkpatrick, David. 2011. "Church Protests in Cairo Turn Deadly." New York Times, October 9. http://www.nytimes.com/2011/10/10/world/middleeast /deadly-protests-over-church-attack-in-cairo.html.

- 2012a. "A Vague Role for Religion in Egyptian Draft Constitution." New York Times, November 9. http://www.nytimes.com/2012/11/10/world /middleeast/draft-egyptian-constitution-adopts-a-role-for-religion.html.

. 2012b. "Egyptian Soccer Riot Kills More Than 70." New York Times, February 1. http://www.nytimes.com/2012/02/o2/world/middleeast/scores -killed-in-egyptian-soccer-mayhem.html.

_. 2012c. "Named Egypt's Winner, Islamist Makes History." New York Times, June 24. http://www.nytimes.com/2012/06/25/world/middleeast /mohamed-morsi-of-muslim-brotherhood-declared-as-egypts-president .html.

- 2012d. "Opponents of Egypt's Leader Call for Boycott of Charter Vote." New York Times, December 12. http://www.nytimes.com/2012/12 /10/world/middleeast/egypt-mohamed-morsi-protests.html.

_. 2013. "Chaos in Egypt Stirs Warning of Collapse." New York Times, January 29. http://www.nytimes.com/2013/o1/3o/world/middleeast/egypt -protest-updates.html.

Kirkpatrick, David, and Mayy El Sheikh. 2012. "Citing Deadlock, Egypt's Leader Seizes New Power and Plans Mubarak Retrial.” New York Times, November 22. http://www.nytimes.com/2012/11/23/world/middleeast /egypts-president-morsi-gives-himself-new-powers.html.

Kirkpatrick, David, and Jodi Rudoren. 2012. "Israel and Hamas Agree to Cease-Fire, After a U.S.-Egypt Push.” New York Times, November 21. http://www.nytimes.com/2012/11/22/world/middleeast/israel-gaza -conflict.html.

Lacroix, Stephane. 2012. "Sheikhs and Politicians: Inside the New Egyptian Salafism.” Brookings Institutions, June. http://www.brookings.edu / /media/research/files/papers/2012/6/07\%2oegyptian\%2osalafism \%2olacroix/stephane\%2olacroix\%2opolicy\%2obriefing\%2oenglish.pdf. 
Lambert, Lisa, and Mark Felsenthal. 2012. "White House Has Concerns about Mursi Declarations in Egypt." Reuters, November 26. http:// www.reuters.com/article/2012/11/26/us-usa-egypt-whitehouseidUSBRE8AP14A20121126.

Loveluck, Louisa. 2013. "Egypt's Static Security Sector.” Foreign Policy, February 6. http://mideast.foreignpolicy.com/posts/2013/o2/o6/egypt_s_static _security_sector.

Mackey, Robert. 2012. "Egypt's Generals Hollow Out Its Presidency." New York Times, June 18. http://thelede.blogs.nytimes.com/2012/o6/18/egypts -generals-hollow-out-its-presidency.

Maged, Amani. 2012. "Square Tango." Al-Ahram Weekly, April 5-11. http:// weekly.ahram.org.eg/2012/1092/eg5.htm.

McCants, William. 2013. "After the Coup: What Morsi's Ouster Means for Radical Islamists.” Foreign Affairs, July 7. http://www.foreignaffairs.com /articles/139565/william-mccants/salafis-after-the-coup.

Nakhoul, Samia. 2012. "Insight: In 'Islamist' Egypt, Generals Still Have Final Say.” Reuters, June 29. http://www.reuters.com/article/2012/o6/29/us -egypt-future-idUSBRE85SoEH20120629.

Ninan, Reena, and Dana Hughes. 2012. "Egypt's President Morsi Wins U.S. and Israeli Gratitude in Gaza Deal." ABC News, November 21. http:// abcnews.go.com/International/egypts-president-morsi-wins-us-israeli -gratitude-gaza/story?id $=17780177$.

Ottaway, Marina. 2013. "You Thought the Brotherhood Was Bad?" Foreign Policy, July 16. http://www.foreignpolicy.com/articles/2013/07/16 /you_thought_the_brotherhood_was_bad_egypt_salafi.

Radwan, Tarek. 2013. "Egypt's Al-Azhar Talks.” Foreign Policy, February 1. http://mideast.foreignpolicy.com/posts/2013/02/01/egypt_s_al_azhar_talks.

Reuters. 2013. "Egyptian Armed Forces Chief Sets Ultimatum.” Reuters, July 1. http://www.reuters.com/article/2013/o7/01/us-egypt-protests-army-text -idUSBRE96014420130701.

Revkin, Mara, and Magdy Samaan. 2012. "Egypt's Salafis Revert to their Authoritarian Roots." Foreign Policy, November 5. http://mideast .foreignpolicy.com/posts/2012/11/o5/egypt_s_salafis_revert_to _their_authoritarian_roots.

Saleh, Yasmine, and Edmund Blair. 2012. "Egypt Agrees to Deal for \$4.8 Billion IMF Loan." Reuters, November 20. http://www.reuters.com/article /2012/11/20/us-egypt-imf-idUSBRE8AJoLK20121120.
Saleh, Yasmine, and Asma Alsharif. 2013. "Egypt's Mursi Defies Army As It Plots Future Without Him.” Reuters, July 2. http://www.reuters.com /article/2013/o7/o2/us-egypt-protests-idUSBRE95QoNO20130702.

Salem, Mahmoud. 2012. "Why the Salafis Agreed to the Constitution." Atlantic Council, December 3. http://www.acus.org/egyptsource/why-salafis -agreed-constitution.

Sallam, Hesham. 2012a. "Morsi Past the Point of No Return." Jadaliyya, December 8. http://www.jadaliyya.com/pages/index/8881/morsi-past-the -point-of-no-return.

2012b. "Morsy, the Coup and the Revolution: Reading between the Red Lines." Jadaliyya, August 15. http://www.jadaliyya.com/pages/index 16870/morsy-the-coup-and-the-revolution_reading-between-.

Shehata, Samer S. 2013. "In Egypt, Democrats vs. Liberals.” New York Times, July 2. http://www.nytimes.com/2013/o7/o3/opinion/in-egypt-democrats -vs-liberals.html?_r=o\&gwh=954D1B4Do4615D8B5A2A78557Bo5D532.

Stacher, Joshua. 2012. "Why the Generals Back Morsi." Foreign Affairs, December 2o. http://www.foreignaffairs.com/articles/138623/joshua-stacher /why-the-generals-back-morsi.

. 2013. "Morsi's Guns: The Officers Backing Egypt's President.” Woodrow Wilson International Center for Scholars, February 5. http://www .wilsoncenter.org/article/morsis-guns.

Tadros, Sherine. 2012. "Egypt's Military Economic Empire.” Al Jazeera, February 15. http://www.aljazeera.com/indepth/features/2012/o2 /2012215195912519142.html.

Taha, Rana. 2013. "National Salvation Front and Tamarod Call on Army to Intervene." Daily News Egypt, July 3. http://www.dailynewsegypt.com /2013/o7/o3/national-salvation-front-and-tamarod-call-on-army-to -intervene/.

Tomlinson, Hugh. 2013. "Iranian Spy Chief's Visit to Cairo was Meant to 'Send Message to America." The Times, January 8. http://www .thetimes.co.uk/tto/news/world/middleeast/article3650461.ece.

Wall Street Journal. 2013. "Qatar to Double Aid to Egypt.” January 8. http:// stream.wsj.com/story/latest-headlines/SS-2-63399/SS-2-139451/.

Watt, Nicholas. 2012. "UK to Advise Egypt on Quelling Sinai Militants." The Guardian, September 26. http://www.guardian.co.uk/world/2012/sep/26 /uk-egypt-sinai-militants 